\title{
Humic acid and boron treatment to mitigate salt stress on the melon plant
}

\author{
Osama Abd El-Salam SHALABY*, Mohamed Moustafa EL-MESSAIRY
}

Received January 16, 2018; accepted June 29, 2018.

Delo je prispelo 16. januarja 2018, sprejeto 29. junija 2018.

\begin{abstract}
Salinity is one of the main abiotic stress factors which limit the growth and productivity of plants, however, the nutritional status of plants is the first brick in the resistance wall against stresses. Therefore, a factorial experiment was undertaken to investigate effects of soil applied humic acid $(0,7,14,21$ 1.ha' $\left.{ }^{1}\right)$ and boron foliar spraying $(0,50,100 \mathrm{ppm})$ and their interaction on growth and yield of melon plant under saline conditions. The results suggested that treatments, soil application of humic acid and boron foliar spray, successfully mitigated the deleterious effects of salt stress and influenced growth and yield of melon plant. Humic acid at $211 . \mathrm{ha}^{-1}$ or boron spray at $50 \mathrm{ppm}$ exhibited an improvement in growth and yield of melon, in terms of plant length, plant fresh and dry mass, chlorophyll (SPAD), fruit mass, total yield, and also leaf nutrient content ( $\mathrm{N}$ and $\mathrm{K}$ ) and total soluble solids (TSS) of fruits, while reduced the sodium content of leaves. The combined treatment of humic acid at 21 1.ha ${ }^{-1}$ and boron spraying at $50 \mathrm{ppm}$ was found to be more effective for the melon plant to improving growth performance and the crop yield by $21 \%$ as compared with the control group under saline conditions.
\end{abstract}

Key words: melon; salt stress; humic acid; boron foliar spray

\section{IZVLEČEK \\ OBRAVNAVANJE S HUMINSKO KISLINO IN BOROM ZA OBLAŽITEV SOLNEGA STRESA PRI MELONI}

Slanostni stres je eden izmed najpomembnejših abiotskih stresnih dejavnikov, ki omejuje rast in produktivnost rastlin in prehranjenost rastline je prvi člen $\mathrm{v}$ odportnosti proti temu stresu. V ta name je bil izveden faktorski poskus za preučevanje učinkov talnega dodajanja huminske kisline $(0,7$, 14, 21 l.ha $\left.^{-1}\right)$ in foliarnega škropljenja $\mathrm{z}$ borom $(0,50,100$ $\mathrm{ppm})$ ter njune interkacije na rast in pridelek melon $\mathrm{v}$ razmerah slanostnega stresa. $\mathrm{Na}$ osnovi rezultatov priporočamo talno uporabo huminske kisline in foliarno škropljenje z borom za uspešno odpravo škodljivih učinkov solnega stresa na rast in pridelek melon. Huminska kislina (21 $1 \mathrm{ha}^{-1}$ ) ali škropljenje $\mathrm{z}$ borom (50 ppm) sta izboljšala rast in pridelek melon preko naslednjih dejavnikov: dolžine rastlin, njihove sveže in suhe mase, vsebnosti klorofila (SPAD), mase plodov, pridelka, vsebnosti hranil $\mathrm{v}$ listih $(\mathrm{N}$ in $\mathrm{K})$ in celokupne vsebnosti topnih snovi $\mathrm{v}$ plodovih (TSS), ob hkratnem zmanjšanju vsebnost natrija v listih. Kombinirano obravnavanje s huminsko kislino $\left(21 \mathrm{l}^{\mathrm{h}} \mathrm{a}^{-1}\right)$ in škropljenje $\mathrm{z}$ borom $(50 \mathrm{ppm})$ se je izkazalo za bolj učinkovito. Pridelek melon je bil v razmerah slanosti v primerjavi s kontrolo za $21 \%$ večji.

Ključne besede: melona; solni stres; huminska kislina; foliarno škropljenje $\mathrm{z}$ borom

\section{INTRODUCTION}

Salinity of both soil and water in the arid and semi-arid regions is one of the major concerns facing the development in the agricultural sector in these regions, higher salt concentrations and excess exchangeable sodium in the soil has led to the deterioration of soil structure and make plants suffer more, the harmful effects of salinity on plants occur due to its adverse effects on osmotic potential, photosynthesis and protein synthesis (Ouni et al., 2014). Salinity negatively affects soil fertility, inhibit plant growth and reduce the productivity via to the excess uptake of some toxic ions, and lack of availability of water and essential nutrients (Khaled, 2011). Romero et al. 1997, Kaya et al. 2007 observed a significant decrease in the plant growth, fresh mass, fruit yield, contents of $\mathrm{Ca}, \mathrm{K}$ and $\mathrm{N}$, and chlorophyll, as well as the rates of photosynthesis and transpiration, while the $\mathrm{Na}$ uptake has increased in the melon plant under salt stress conditions. The high salt concentration in the soil solution decreases the water potential, reduces the osmotic potential of plant cells,

1 Plant Production Department, Desert Research Center, 1 Mathaf El Matarya St. Cairo - Egypt, *corresponding author: o.a.shalaby@ gmail.com 
and slow down the division and elongation of plant cells (Kusvuran et al. 2007). Humic acid is an organic matter found naturally in the soil, provide several benefits to the soil with regard to structure improvement, retain moisture and microbial activity, also act as a chelating agent, which prevent fixation, leaching, and oxidation of elements and thus promote the ion exchange capacity and nutrient availability in the soil (Ouni et al., 2014), humic acid is one of the organic-mineral fertilizers that increases the soil fertility (Kahraman, 2017), has positive effects at the different stages of plant growth, from seed germination and seedling growth to the development of shoots and roots (Adani et al.,1998), acts like the plant growth regulators, stimulates growth, development and yield (Karakurt et al., 2009), enhances enzyme activity and the permeability of cell membranes (Asri et al.,2015). A good conditioner for the saline soil which reduces the uptake of toxic elements e.g. sodium ions and increases the plant's ability to resist the deleterious effects of salt stress (Aydin et al., 2012). Boron is one of the essential micronutrient elements, boron in the proper concentration has several physiological roles within the plant including the function and integrity of cell walls and membranes, sugar transport, differentiation, and root elongation, as well as the metabolism of protein, carbohydrate, nucleic acid, and indole acetic acid (Pinho et al., 2010), plays a vital role in the division and elongation of plant cells as well as in the osmotic adjustment, metabolism of phenols and oxidative stress (Naeem et al., 2017). It is necessary for the flowering and fruiting processes, from the germination of pollen and growth of pollen tube to growth and development of fruit (Krudnak et al., 2013), enhances the nutrient status, marketable yield and shelf life of fruits (Davis et al., 2003). Boron foliar spray mitigates the deleterious effects of salt stress and enhances the growth performance and productivity (Hellal et al., 2015). However, the availability of boron element decreases when the soil $\mathrm{pH}$ is higher than 7 in the saline-alkaline soil (Brady, 1990), boron deficiency has an unfavorable impact on the physiological processes of plants, thus diminishing growth and yield of plants (Pinho et al., 2010).

Melon (Cucumis melo 'Galia') is one of the popular vegetables in Egypt, belonging to the Cucurbitaceae family. Melon is classified as a moderately sensitive crop to salinity (Olave and Guzman, 2004). Salinity is the most important problem facing the cultivation of melon plant in the dry and semi-dry regions (Kusvuran et al. 2007). Yasar et al 2006 reported that salt stress causes plant growth inhibition as well as metabolic disturbances, consequently losses of yield and quality. Our experiment was designed to investigate the influence of soil application of humic acid and boron foliar spray on melon plants grown under saline conditions and to determine their roles in reducing the damage of salt stress on plants.

\section{MATERIALS AND METHODS}

The experiment was conducted at the experimental farm of Desert Research Center at Ras Sudr, Sinai, Egypt in 2015 and 2016. Soil samples were taken from the experimental site and analyzed according to the methods described by Klute (1986) and Page et al. (1982), detailed soil description is provided in Table 1.

Table1: Chemical properties of the experimental soil

\begin{tabular}{|c|c|c|c|c|c|c|c|c|c|c|c|c|c|}
\hline \multirow{3}{*}{ 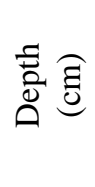 } & \multirow{3}{*}{$\stackrel{T}{2}$} & \multirow{3}{*}{ U } & \multicolumn{7}{|c|}{$\begin{array}{l}\text { Saturation soluble extract } \\
\qquad\left(\mathrm{mg} .100 \mathrm{~g}^{-1}\right)\end{array}$} & \multicolumn{4}{|c|}{$\begin{array}{l}\text { Available nutrients } \\
\qquad\left(\mathrm{mg} \mathrm{kg}^{-1}\right)\end{array}$} \\
\hline & & & \multicolumn{3}{|c|}{ Cations } & \multicolumn{4}{|c|}{ Anions } & \multirow{2}{*}{$\mathrm{N}$} & \multirow{2}{*}{$\mathrm{P}$} & \multirow{2}{*}{$\mathrm{K}$} & \multirow{2}{*}{$\mathrm{Fe}$} \\
\hline & & & $\mathrm{Ca}^{++}$ & $\mathrm{Mg}^{++}$ & $\mathrm{Na}^{+}$ & $\mathrm{CO}_{3}^{-}$ & $\mathrm{HCO}_{3}{ }^{-}$ & $\mathrm{Cl}^{-}$ & $\mathrm{SO}_{4}{ }^{=}$ & & & & \\
\hline $0-30$ & 7.7 & 8.65 & 24.5 & 5.2 & 57.2 & 0.0 & 6.0 & 61.5 & 26.2 & 26.0 & 5.1 & 51.5 & 4.2 \\
\hline $30-60$ & 7.9 & 7.35 & 16.8 & 3.8 & 42.5 & 0.0 & 3.5 & 49.0 & 23.5 & 18.5 & 3.4 & 35.3 & 3.4 \\
\hline
\end{tabular}

Based on the soil analysis the soil $\mathrm{pH}$ is 7.7 , indicating a decrease in the availability of boron under these conditions (Brady, 1990). The experiment was arranged in a split plot design with three replications, the main plot factor was humic acid levels $\left(0,7,14,21\right.$ 1.ha $\left.^{-1}\right)$ and the subplot factor was boron foliar application levels $(0$, $50,100 \mathrm{ppm})$ after consideration of previous studies.
Humic acid treatment was carried out in the soil using a potassium humate compound $83 \%$ obtained from Union company for agricultural development. Boron applications were made using boric acid (B 17\%) with a back-sprayer, while the humic acid treatments were performed through the drip irrigation system. In the fourth week of March, the 30 days old seedlings of 
melon (Cucumis melo 'Galia') were transplanted into the soil at a spacing of $50 \mathrm{~cm}$ within rows, where each plot contained 5 rows, $4 \mathrm{~m}$ in length. Standard agricultural practices were followed for fertilization, irrigation, and pesticides for all experimental plots as per the recommendations of the Egyptian Ministry of Agriculture, ,except for the application of humic acid and boron spraying treatments which were conducted three times with a 15-day interval, starting from two weeks after transplanting. Five plants per treatment were harvested after 60 days after transplanting, and plant length, fresh mass and chlorophyll reading (SPAD) were recorded. Plant samples were washed with distilled water and dried at $70{ }^{\circ} \mathrm{C}$ for $72 \mathrm{~h}$, and dry mass of plants was determined. For chemical analysis, plant leaf samples were dried, ground and digested with concentrated sulfuric acid, and then nitrogen content was determined according to the Kjeldahl method (Jackson, 1973), and flame photometer was used for the potassium, calcium and sodium analyses, while phosphorus was determined by spectrophotometric method (Irri, 1976). Yield measurements were also taken, such as fruit mass, fruit soluble solids (TSS) using a hand-held refractometer and total yield. Data for this study were analyzed statistically using the MSTAT software (MSTAT-C, 1991), and significant differences between means were obtained using Duncan's multiple range test at a significance level of $\mathrm{P}<0.05$ as described by Snedecor and Cochran (1982).

\section{RESULTS AND DISCUSSIONS}

\subsection{Vegetative growth}

Soil-applied humic acid has a significant impact on growth and development of melon plants under saline conditions as shown in Fig.1. Increasing concentrations of humic acid caused a gradual increase in the vegetative growth parameters in terms of plant length, leaf chlorophyll reading (SPAD), and fresh and dry mass as compared with the control group. Maximum values of growth parameters were recorded at $211 . \mathrm{ha}^{-1}$ of humic acid.
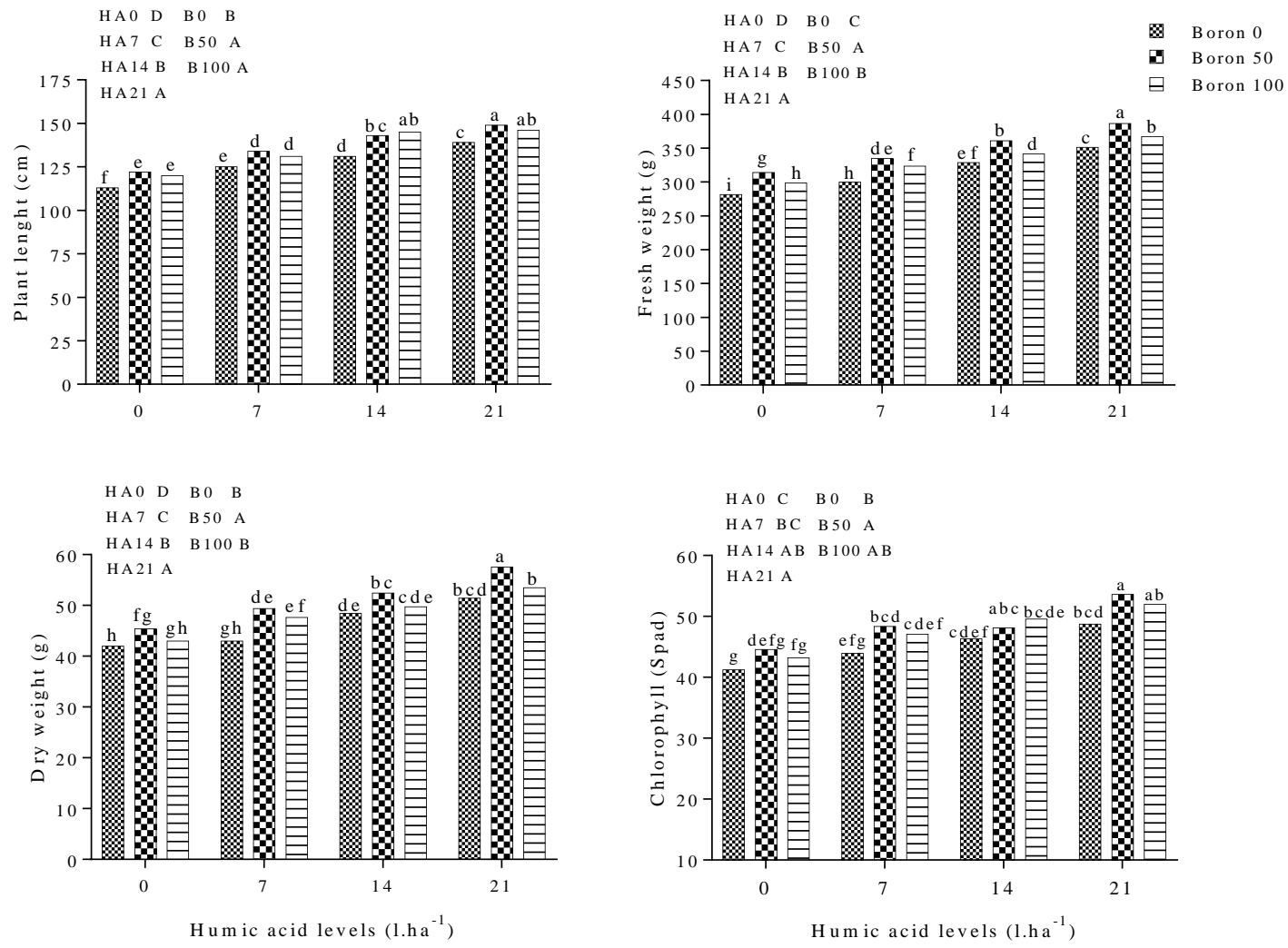

Figure 1: Main effects and interactions for humic acid and boron on plant length, plant fresh and dry mass and chlorophyll content of melon plants grown under saline conditions 
The promotion of vegetative growth by humic acid application has also been reported in many studies, Adani et al. (1998) on tomato, Karakurt et al. (2009) on pepper, Aydin et al. (2012) on bean under salt stress, and Mirdad (2016) on lettuce.Ahmad et al. (2016) found that the humic acid application at $20 \mathrm{~kg} \mathrm{ha}^{-1}$ improved growth of canola plant, while $70 \mathrm{~kg} \mathrm{ha}^{-1}$ was the most appropriate for cowpea growth (Kahraman, 2017). Boron spray improves vegetative growth of melon plant, plant growth parameters (plant length, leaf chlorophyll reading, plant fresh and dry mass) were significantly increased by the boron application (Fig.1). The highest values of growth parameters were recorded with boron spray $50 \mathrm{ppm}$. These results are in agreement with Davis et al. (2003) on tomato, Baranwal et al. (2017) on guava and Hellal et al. (2015) on faba bean under salt stress. The interaction between humic acid and boron had a synergistic impact on the vegetative growth under salt stress conditions, $211_{1 . h a^{-1}}$ of humic acid plus 50 ppm boron spray was the superior treatment for the melon plant.

\subsection{Chemical components}

The data in Figs. 2 and 3 indicate that chemical components of the melon plant were significantly affected by humic acid treatment. The content of potassium and nitrogen in leaves and TSS of fruits were increased, whereas calcium and sodium contents in leaves were decreased with increasing levels of humic acid. $211 . \mathrm{ha}^{-1}$ of humic acid led to the highest values of $\mathrm{N}, \mathrm{K}$, and TSS contents and the lowest values of $\mathrm{Ca}$ and $\mathrm{Na}$. However, under salt stress conditions the potassium absorption is markedly reduced due to the competitive effect with sodium, where plants absorb $\mathrm{Na}$ ions more than necessity, resulting in malnutrition status in plants grown under these conditions (Kusvuran et al. 2007). These results are in consonance with the finding of Khaled (2011) for $\mathrm{N}, \mathrm{K}$, and $\mathrm{Na}$ in corn, Asri et al. (2015) for N, K, and TSS in tomato, Ahmad et al. (2016) for N and K in canola, Mirdad (2016) for N, K and TSS in lettuce, Kahraman (2017) for $\mathrm{K}$ and $\mathrm{Ca}$ in cowpea, as well as, humic acid increases the contents of $\mathrm{N}$ and $\mathrm{K}$, and decreases sodium content of bean plant under saline conditions (Aydin et al., 2012). The positive effect of humic acid on plants may be due to improving chemical, physical and biological properties of the soil, elements chelation and $\mathrm{pH}$ adjustment (Karakurt et al., 2009), thus the low soil pH may affect plant growth indirectly, at the low soil $\mathrm{pH}$ the availability of many elements increases while the other nutrients such as calcium were limited (Yan et al. 1992). Boron foliar application led to significant increases in the contents of $\mathrm{N}, \mathrm{K}$, and $\mathrm{Ca}$ in plant leaf, and fruit TSS, while the sodium content in leaves was decreased as compared with the control group, however, the increase and decrease in the chemical parameters were highly statistically significant in plants sprayed with $50 \mathrm{ppm}$ of boron. The effect of boron spray on the content of chemical parameters in plants has also been observed by Davis et al. (2003) for N, K and Ca in tomato, Hellal et al. (2015) for $\mathrm{K}, \mathrm{Ca}$ and $\mathrm{Na}$ in faba bean and Baranwal et al. (2017) for TSS in guava fruits. A cooperative interaction between the humic acid $211 . \mathrm{ha}^{-1}$ and boron spray $50 \mathrm{ppm}$ was obtained, which increased $\mathrm{N}, \mathrm{K}$, and TSS values and decreased $\mathrm{Na}$ and $\mathrm{Ca}$ values, whereas the highest values of $\mathrm{Na}$ and $\mathrm{Ca}$ were recorded with the control treatment. 

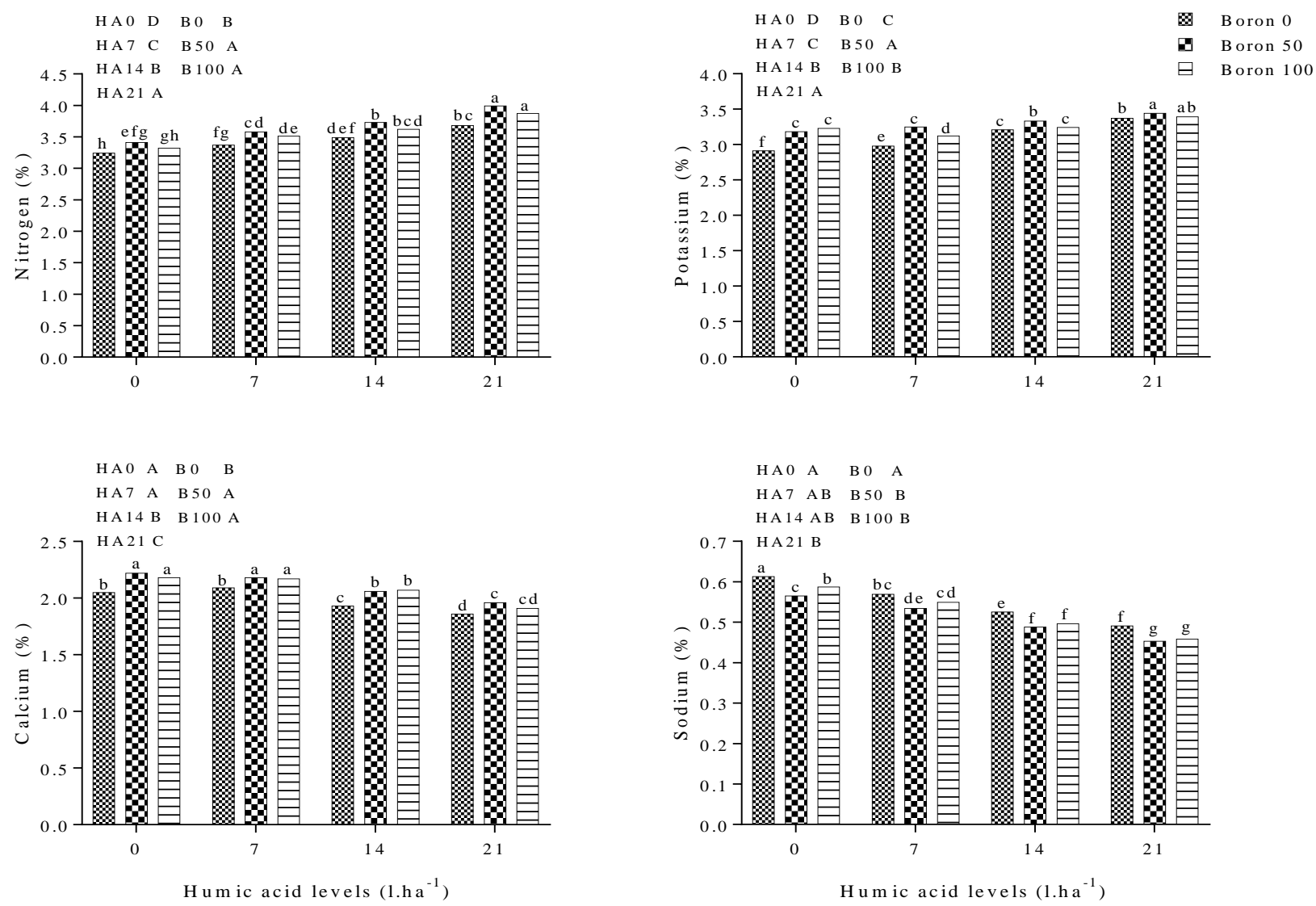

Figure 2: Main effects and interactions for humic acid and boron on nitrogen, potassium, calcium and sodium contents of melon plants grown under saline conditions

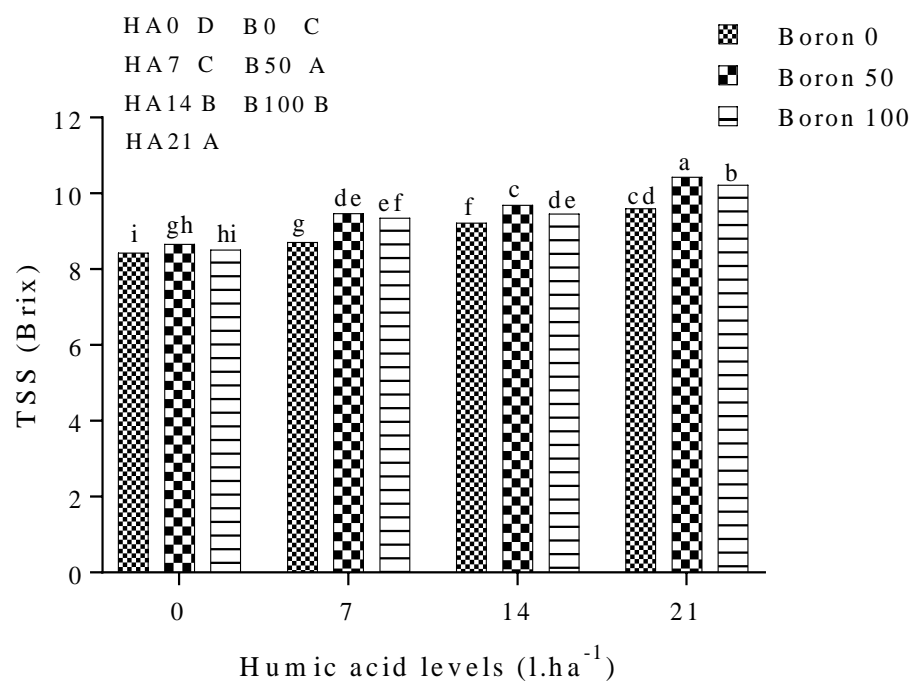

Figure 3: Main effects and interactions for humic acid and boron on TSS content of melon fruits under saline conditions 


\subsection{Yield}

A significant increase in fruit mass and total yield of the melon plant was obtained with increasing levels of humic acid under saline conditions as shown in Fig. 4. Fruit mass and total yield were correlated positively and significantly with the soil application of humic acid, the increase was more pronounced in the plants which received $211 . \mathrm{ha}^{-1}$ of humic acid. There are many studies that indicate the stimulatory influence of humic acid on crop productivity Karakurt et al. (2009) in pepper, Asri et al. (2015) in tomato, Ahmad et al. (2016) in canola and Kahraman (2017) in cowpea. Fruit mass and total yield of the melon plant were significantly increased with boron foliar spray (Fig. 4). The maximum values of fruit mass and total yield were obtained by the application of boron spray $50 \mathrm{ppm}$. The promotion effect of boron application on the plant productivity has also been detected by many studies, Davis et al. (2003) in tomato, Baranwal et al. (2017) in guava ,also by Hellal et al. (2015) in faba bean under saline conditions. The interaction between humic acid and boron showed a positive effect on the yield of melon under saline conditions, the highest values for fruit mass and total yield were recorded in plants received 211. ha $^{-1}$ of humic acid plus $50 \mathrm{ppm}$ of boron spray.
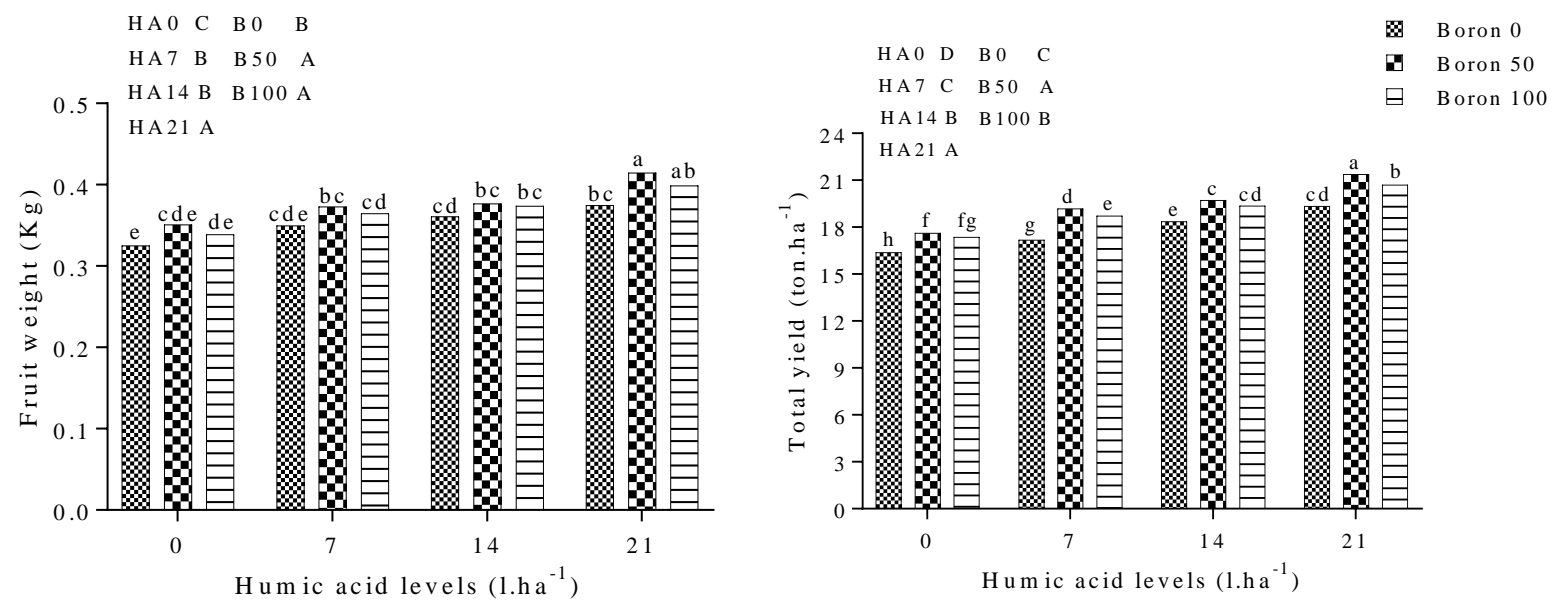

Figure 4: Main effects and interactions for humic acid and boron on fruit mass and total yield of melon plants grown under saline conditions

Humic acid increases the permeability of the cell membrane and transportation of nutrients (Aydin et al., 2012), as well as increases the root elongation and growth of lateral roots and root hairs and decreases the electrical conductivity of soil (Ahmad et al., 2016). Boron application stimulates the physiological processes within plants under salinity conditions such as osmotic adjustment, photosynthetic rate, antioxidant enzymes activity (superoxide dismutase, catalase, peroxidase and ascorbate peroxidase), and total protein and nucleoprotein synthesis (Naeem et al., 2017), also affect flowering process, it increases viability and germination of pollen and promotes the fruit composition (Kroenke et al., 2013). These effects together could mitigate the adverse impact of salt stress on plant and increase nutrient availability in the soil and ability of plant roots to uptake the nutrients, thus the contents of potassium and nitrogen in plant leaves has increased, hence, improved the vegetative growth performance and increased crop yield of melon plant under saline conditions. 


\section{CONCLUSIONS}

1- The deleterious effect of salt stress on melon plant has been alleviated by the treatments with humic acid and boron.

2- Vegetative growth and chemical contents of melon plants improved under saline conditions using humic acid and boron treatments.
3- $\quad$ The fruit mass, fruit TSS and total yield were increased in the plants receiving humic acid or boron.

4- Plants grown under saline conditions received a double benefit through the treatment with humic acid and boron. The best results were obtained by the combination of soil-applied humic acid at $211 . \mathrm{ha}^{-1}$ and boron spray at $50 \mathrm{ppm}$.

\section{REFERENCES}

Adani, F., Genevini, P., Zaccheo, P. and Zocchi, G. (1998).The effect of commercial humic acid on tomato plant growth and mineral nutrition. Journal of plant nutrition, 21(3), 561-575. doi:10.1080/01904169809365424

Ahmad, S., Daur, I., Al-Solaimani, S.G., Mahmood, S., Bakhashwain, A.A., Madkour, M.H. and Yasir, M. (2016). Effect of rhizobacteria inoculation and humic acid application on canola (Brassica napus L.) crop. Pakistan Journal of Botany, 48(5), 21092120 .

Asri, F.O., Demirtaş, E.I. and Ari, N. (2015). Changes in fruit yield, quality and nutrient concentrations in response to soil humic acid applications in processing tomato. Bulgarian Journal of Agricultural Science, 21(3), 585-591.

Aydin, A., Kant, C. and Turan, M. (2012). Humic acid application alleviate salinity stress of bean (Phaseolus vulgaris L.) plants decreasing membrane leakage. African Journal of Agricultural Research, 7(7), 1073-1086. doi:10.5897/AJAR10.274

Baranwal, D., Tomar, S., Singh, J.P. and Maurya, J.K. (2017).Effect of foliar application of zinc and boron on fruit growth, yield and quality of winter season Guava (Psidium guajava L.). International Journal of Current Microbiology and Applied Sciences, $6(9)$

1525-1529. doi:10.20546/ijcmas.2017.609.186

Brady, N.C. (1990). The Nature and Properties of Soils.Tenth Ed. MacMillan Publishing Company. New York.

Davis, J.M., Sanders, D.C., Nelson, P.V., Lengnick, L. and Sperry, W.J. (2003). Boron improves growth, yield, quality, and nutrient content of tomato. Journal of the American Society for Horticultural Science, 128(3), 441-446.
Hellal, F.A., El-Sayed, S.A.A., Zewainy, R.M. and Abdelhamid, M. (2015). Interactive effects of calcium and boron application on nutrient content, growth and yield of faba bean irrigated by saline water. International Journal of Plant \& Soil Science, 4(3), 288-296. doi:10.9734/IJPSS/2015/8955

Irri, (1976). Laboratory Manual for Physiological Studies on Rice.3rd edn (Ed. by Souchi Yoshida, D. A. Forno, J. H. Cock \& K. A. Gomez), pp. 17-23. The International Rice Research Institute, Los Banos, Phillipines.

Jackson, M.L. (1973). Soil chemical analysis.Prentice Hall of India Pvt. Ltd. New Delhi, India. 187 p.

Kahraman, A. (2017). Effect of humic acid doses on yield and quality parameters of cowpea [Vigna unguiculata L.)Walp] cultivars.Legume Research: An International Journal, 40(1), 155-159

Karakurt, Y., Unlu, H., Unlu, H. and Padem, H. (2009).The influence of foliar and soil fertilization of humic acid on yield and quality of pepper. Acta Agriculturae Scandinavica Section B-Soil and Plant Science, 59(3), 233-237. doi:10.1080/09064710802022952

Kaya, C., Tuna, A.L., Ashraf, M. and Altunlu, H., 2007. Improved salt tolerance of melon (Cucumis melo L.) by the addition of proline and potassium nitrate. Environmental and Experimental Botany, 60(3), 397-403. doi:10.1016/j.envexpbot.2006.12.008

Khaled, H. and Fawy, H.A. (2011).Effect of different levels of humic acids on the nutrient content, plant growth, and soil properties under conditions of salinity. Soil and Water Research, 6(1), 21-29. doi:10.17221/4/2010-SWR

Klute, A. (1986). Methods of soil analysis, part I, 2nd $e d$, USA: Madison, Wisconsin.

Krudnak, A., Wonprasaid, S. and Machikowa, T. (2013). Boron affects pollen viability and seed set 
in sunflowers. African Journal of Agricultural Research, 8(2), 162-166, doi:10.5897/AJAR12.1471

Kusvuran, S., Yasar, F., Ellialtioglu, S. and Abak, K., 2007. Utilizing some of screening methods in order to determine of tolerance of salt stress in the melon (Cucumis melo L.). Research Journal of Agriculture and Biological Sciences, 3(1), 40-45.

Mirdad, Z.M. (2016). Effect of $\mathrm{N}$ fertigation rates and humic acid on the productivity of crisp head lettuce (Lactuca sativa L.) grown in sandy soil. Journal of Agricultural Science, 8(8),

149-157. doi:10.5539/jas.v8n8p149

MSTAT-C (1991). A Software Program for the Design, Management, and Analysis of Agronomic Research Experiments. Michigan State University, East Lansing, MI, USA.

Olave, J. and Guzmán, M.(2004).Effects of N-form and saline priming on germination and vegetative growth of Galia-type melon (Cucumis melo L. cv. Primal) under salinity. Acta Horticulture, 659, 253260. doi:10.17660/ActaHortic.2004.659.32

Ouni, Y., Ghnaya, T., Montemurro, F., Abdelly, C. and Lakhdar, A. (2014). The role of humic substances in mitigating the harmful effects of soil salinity and improve plant productivity. International Journal of Plant Production, 8(3), 353-374.

Page, A. L., Miller, R. H., and Keeney, D. R. (1982). Methods of soil analysis, part II, 2nd ed, Wisconsin.
Pinho, L.G., Campostrini, E., Monnerat, P.H., Netto, A.T., Pires, A.A., Marciano, C.R. and Soares, Y.J.B. (2010). Boron deficiency affects gas exchange and photochemical efficiency (JPI test parameters) in green dwarf coconut. Journal of plant nutrition, $33 \quad$ (3), 439-451. doi:10.1080/01904160903470471

Romero, L., Belakbir, A., Ragala, L. and Ruiz, J.M., 1997. Response of plant yield and leaf pigments to saline conditions: effectiveness of different rootstocks in melon plants (Cucumis melo L.). Soil Science and Plant Nutrition, 43(4), 855-862. doi:10.1080/00380768.1997.10414652

Snedecor, G.W. and W.G. Cochran .(1982). Statistical methods. 7th ed. Iowa State Univ. Press Lowa, U.S.A., 485 p.

Yan, F., Schubert, S. and Mengel, K., 1992. Effect of low root medium $\mathrm{pH}$ on net proton release, root respiration, and root growth of corn (Zea mays L.) and broad bean (Vicia faba L.). Plant Physiology, 99(2), 415-421. doi:10.1104/pp.99.2.415

Yasar, F., Kusvuran, S. and Ellialtioglu, S., 2006. Determination of anti-oxidant activities in some melon (Cucumis melo L.) varieties and cultivars under salt stress. The Journal of Horticultural Science and Biotechnology, 81(4), 627-630. doi:10.1080/14620316.2006.11512115 